\title{
Funksionele aspekte van spoorvervoereindpunte wat die suksesvolle vervoer van goedere per spoor ondersteun
}

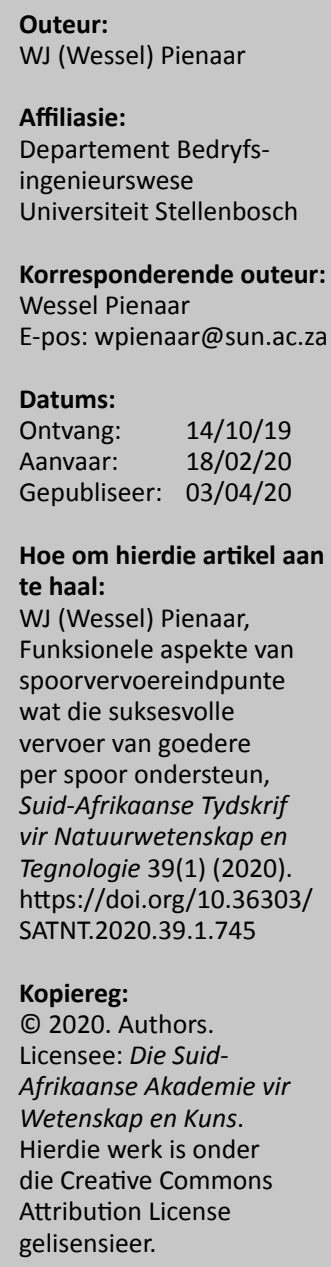

\begin{abstract}
Hierdie artikel bied 'n oorsig van die funksionele aspekte van spoorvervoereindpunte wat die suksesvolle lewering van goederespoordienste kan ondersteun. Ten aanvang word die primêre en sekondêre funksies van goederevervoereindpunte in die algemeen bespreek, waarna spoorvervoereindpunte in die besonder bespreek word. Spoorvervoereindpunte bestaan uit verskeie werftipes wat elkeen ingerig is om sekere funksies te verrig of werksaamhede te hanteer. Die primêre en sekondêre funksies van al die werftipes word vermeld. Daarna word die funksies bespreek van die vier breë klasse goederespoorvervoereindpunte wat vandag aangetref word, naamlik (1) losmaat-, (2) grootmaat-, (3) opry-afry- en (4) intermodale eindpunte. Grootmaateindpunte word verder verdeel in ertseindpunte, eindpunte by die tenkwerwe van olieraffinaderye en chemiese aanlegte, en eindpunte by graansuiers. Die soorte treine, spoortrokke en hanteringstoerusting wat by elke eindpuntklas aangewend word en die goederesoorte wat by elkeen hanteer word, word vermeld.
\end{abstract}

Trefwoorde: funksionele aspekte, spoorvervoereindpunte, suksesvolle vervoer, goedere

\begin{abstract}
Functional aspects of rail transport terminals that support the successful transportation of freight by rail: This review article offers an overview of functional aspects of rail transport terminals that can enhance the success of freight rail transport services. First, the primary and secondary functions of freight transport terminals in general are discussed, followed by a discussion of rail transport terminals in particular. Rail transport terminals consist of various yard types, each of which is adapted to fulfil certain functions or activities. The primary and secondary functions of each yard type are mentioned. Then the functions of the four broad classes of freight rail transport terminals found today are discussed. These rail transport terminals are break-bulk, bulk, roll-on roll-off and intermodal terminals. Bulk terminals are further divided into ore terminals, terminals at the tank yards of oil refineries and chemical production plants, and terminals at grain silos. The train types, wagon types and handling-equipment types employed at each class of terminal and the type of freight that is handled at each are pointed out.
\end{abstract}

Key words: functional aspects, rail transport endpoints, successful transportation, goods

\section{Inleiding}

Hierdie oorsigartikel is die derde van drie. Die eerste van die vorige twee artikels het gehandel oor goederevervoermarksegmente wat belofte toon om winsgewend deur spoorvervoer bedien te word indien die aanbod daarvan doelmatig en doeltreffend geskied (Pienaar 2019), en die tweede oor die plasing van spoorvervoereindpunte om 'n goederespoorstelsel so toeganklik te maak dat dit kan bydra tot die winsgewendheid van goederevervoerdienste per spoor (Pienaar 2020). Hierdie (laaste) aflewering handel oor die rol van spoorvervoereindpuntgeriewe om die suksesvolle vervoer van goedere per spoor te ondersteun.

\section{Studiebehoefte}

Die oogmerke van hierdie artikel is om 'n oorsig te gee van eerstens die veranderde rol wat goederespoorvervoereindpunte sedert die ekonomiese deregulering van goederevervoer begin aanneem het, en tweedens die primêre en sekondêre funksies wat spoorvervoereindpuntgeriewe vandag vervul om die suksesvolle vervoer van goedere per spoor te ondersteun. 


\section{Ondersoekmetode}

Die ondersoek is uitgevoer deur stede en vervoereindpunte in nywerheidslande te besoek waar goederespoorvervoerbedrywighede op groot skaal plaasvind, en deur onderhoude en korrespondensie met verteenwoordigers van goederespoorvervoeroperateurs te voer. Die ondersoeke ter plaatse is aangevul deur 'n literatuurstudie oor die onderwerp van die ondersoek. Altesaam 35 plekke op ses kontinente waar spoorvervoerbedrywighede plaasvind, is besoek. Die volledige lys plekke wat vir navorsingsdoeleindes besoek is, word in die eerste aflewering van hierdie reeks artikels vermeld (Pienaar 2019:168-179).

\section{Algemene funksies van goedere- vervoereindpunte}

Elke vervoermodus bestaan uit vier hoofkomponente, wat noodsaaklike elemente van enige vervoerstelsel is, naamlik die weg, die karwei-eenheid, die aandryfeenheid en die eindpunt (Faulks 1982:11; Benson en Whitehead 1975:15). Die weg is die roete waarlangs die verkeer beweeg; die karwei-eenheid is die deel van vervoerstelsels wat die loonvrag (d.w.s. goedere en/of passasiers) dra; die aandryfeenheid dryf die vervoermiddel aan; en die eindpunt is die plek waar een vervoerskakel eindig en die volgende een begin. In die geval van 'n goederespooronderneming, soos Transnet Freight Rail, is hierdie fisiese komponente onderskeidelik die treinspore, die goederetrokke, die lokomotiewe, en die eindpunte, wat stasies en hul verwante werftipes insluit. Hierdie artikel word gewy aan die funksies van laasgenoemde.

Goederevervoereindpunte vervul verkeersfunksies en voertuigfunksies. Die volgende vyf verkeersfunksies kan uitgeken word: dié van (1) toegangs- en uitgangsverlening, (2) buffering, (3) goedereoordrag, (4) vragkonsolidering en (5) vragverdeling. Hierdie vyf funksies word vervolgens oorsigtelik bespreek.

Toegangs- en uitgangsverlening het betrekking op die ontvangs van versenders se goedere van buite die vervoerstelsel en die lossing van ontvangers se goedere na buite die vervoerstelsel. Goederevervoereindpunte is hiervoor nie net aan die einde van 'n roete geleë nie, maar ook op aangewese plekke langs 'n roete of waar verskillende roetes bymekaarkom, vertak of kruis.

Buffering verwys daarna dat aangekome goedere in 'n transitopakhuis opgeberg word en later, na gelang dit vir aansending benodig word, uit opberging onttrek word. Die hou van buffervoorraad by 'n eindpunt word dikwels genoodsaak omdat goedere met groot reëlmaat met vergelykenderwys kleiner voertuie toegevoer word maar met kleiner, wisselvallige of onsekere reëlmaat met veel groter voertuie afgevoer word.

Goedereoordrag kan plaasvind deur (1) die regstreekse oorlaai van goedere van aangekome voertuie af na voertuie, in dieselfde vervoermodus of in verskillende vervoermodusse, wat op vertrek staan, (2) kruisversending, wat behels dat goedere van aangekome voertuie af op 'n platform of 'n dok geplaas word, waar dit oorstaan totdat dit later op vertrekkende voertuie gelaai word, of (3) herverskeping, wat beteken goedere word ná buffering gelaai op voertuie wat gaan vertrek.

Vragkonsolidering vind plaas wanneer 'n verskeidenheid van kleiner besendings ontvang en tot groter vragbesendings vir langafstandversending gekombineer word, gewoonlik trokke met deelvragte wat tot voltrokvragte gekonsolideer word. Dit behels ook die dra van goedere in die grootse moontlike trokke en die saamvoeging van kort treine tot die langs moontlike treine vir die deel van die reis op lyne wat alle verkeer gemeen het. Konsolidering help om voertuigdravermoë ten beste te benut.

Vragverdeling vind plaas wanneer groot vragte in kleiner vrageenhede geskei word, gewoonlik vir aflewering by verskeie bestemmings. Dit is die teenoorgestelde van vragkonsolidering en dit vind merendeels by intermodale lokuseindpunte plaas waar houers van aangekome houertrokke na houerpadvoertuie oorgeplaas word, of by opstelwerwe waar voltrokvragte losmaatgoedere, tenktrokke en houertrokke wat deel van 'n trokvragtrein is, ontkoppel en op 'n private sylyn afgelewer word.

Bogenoemde vyf aktiwiteite word in hierdie artikel as die primêre funksies van 'n goederevervoereindpunt beskou.

Afgesien van dié vyf primêre verkeersfunksies, verskaf eindpunte in die algemeen ook sekondêre dienste wat voertuiggerig is. Afhangende van die grootte van die eindpunt kan dit voertuiginspeksie, brandstofhervulling, die beskutting van en parkering vir voertuie, en instandhouding van en herstelwerk aan voertuie en toerusting insluit.

Die werftipes waarbinne die onderskeie funksies van goederespoorvervoereindpunte uitgevoer word, word in Tabel 1 getoon.

\section{Funksies van goederespoorvervoer- eindpunte Oorsig}

In spoorvervoer word die funksies van 'n eindpunt deur 'n spoorwegstasie (of treinstasie) vervul. In 'n spoorvervoerkonteks word in die algemeen bloot na 'n "stasie" verwys. "Eindpunt" beteken hier 'n fasiliteit waar treine kan stop sodat passasiers kan op- of afklim en/of waar goedere op- en afgelaai kan word, eerder as dat dit verwys na die einde van die spoorlyn self. Soos in die twee artikels wat hierdie een voorafgegaan het, word "eindpunt" en "stasie" in hierdie artikel sinoniem gebruik.

Byna alle spoorstasies het minstens een platform of pad langs die spoor, terwyl groter stasies verskeie platforms 
het. In goederespoorvervoer verwys "platform" na enige soort verhoogte plat vlak langs ' $n$ spoorsylyn waar goedere hanteer, tydelik geplaas en op- en afgelaai kan word.

RailNet Europe (2014:37) definieer 'n spoorstasie as "'n spoorwegaanleg wat óf oop is vir die publiek óf nie oop is nie, wat meesal personeel het en wat ontwerp is vir een of meer van die volgende bedrywighede:

- Die vorming, afsending, ontvangs en tydelike oorstaan van treine

- Die oorstaan en opstel van rollende materiaal

- Die aan boord gaan en afklim van passasiers

- Wanneer oop vir die publiek, die voorsiening van geriewe vir die koop van kaartjies

- Die laai en aflaai van goedere" (Skrywer se vertaling)

Uit bostaande is dit duidelik dat spooreindpunte stasies sowel as hulle verwante werftipes insluit.

Werflyne kan gebruik word vir die opstel van treine (spoorlyne wat gebruik word om treine saam te stel); rangeerwerk (lyne waarop trokke en ander rollende materiaal om watter rede ook al na 'n ander posisie verskuif word); oorstaan en parkering van rollende materiaal; en die laai en ontlaai van trokke. Sylyne kan ook instandhoudingsof ander toerusting hou, treine toelaat om mekaar verby te steek, of om hulplokomotiewe tussen lopies te parkeer. Hierdie groep sylyne vorm gesamentlik werflyne, wat hoofsaaklik tot die volgende groepeer kan word: (1) 'n ontvangs- of aankomswerf, (2) 'n oordrag- en rangeerwerf, (3) 'n herstel- en instandhoudingswerf, (4) 'n lokomotiefdepot, (5) 'n opstelwerf en in sommige gevalle ook 'n eenheidstreinsylyn (opstelwerwe kom slegs by losmaateindpunte voor - vergelyk onderafdeling 5.2.1), en (6) 'n vertrekwerf. Die funksies wat by hierdie werwe vervul word, word vervolgens kortliks beskryf.

'n Ontvangswerf is ' $n$ werf waar lokomotiewe losgemaak word van die trokke van 'n trein wat pas aangekom het en die trokke vir meganiese probleme ondersoek word. Klein herstelwerk, byvoorbeeld die vervanging van remblokke kan hier gedoen word, terwyl trokke wat nie meer verder kan gaan nie, na die herstelwerf geneem word. Nadat die inspeksie van die trokke afgehandel is, moet hulle so gou moontlik na die opstelwerf gerangeer word om nie inkomende treine te vertraag nie.

'n Oordrag- en rangeerwerf is 'n werf waar stelle trokke deur'n deurgaande trein gelaat of opgetel word, gewoonlik by 'n aansluitstasie wat twee of meer lusse langs die looplyn het, of trokke om watter rede ook al rondbeweeg (rangeer) word (slegs een lus langs 'n looplyn word bloot as 'n verbysteeklus beskou). Oordrag- en rangeerbewegings word met rangeerlokomotiewe uitgevoer.

In ' $n$ herstelwerf of instandhoudingswerf word trokinstandhouding en herstelwerk onderneem. 'n Lokomotiefdepot is ' $\mathbf{n}$ werf waar lokomotiewe oorstaan (sogenaamd "op stal getrek word"), waar hulle brandstof inneem en waar hulle versien word.

'n Opstelwerf is toegerus met meervoudige lyne met spesiale uitleg- en tegniese geriewe waar die verdeling van losvragtreine, die sortering van trokke vir verskillende bestemmings en die opstelling van volledige losvragtreine met die oog op die doelmatige bedryf daarvan plaasvind. Die beste manier om kostedoelmatigheid te bereik, is om die grootste massa en hoeveelheid vrag per tydperk met die mins moontlike totale treinafstand en aantal treinritte te vervoer. Hierdie doelwit word nagestreef deur verkeerskonsolidering en die beskikbaarheid van gepaste tegnologie.

In breë trekke is daar by spoorvervoer vier metodes waarop goedereverkeer konsolideer word (Pienaar 2017:82):

- Vragkonsolidering: Dit verwys na trokke met deelvragte wat tot voltrokvragte gekonsolideer word, die dra van goedere in die groots moontlike trokke en die saamvoeg van kort treine tot die langs moontlike treine vir die deel van die reis wat alle verkeer op gemeenskaplike lyne aflê.

- Roetekonsolidering: Dit verwys na die saampot van verkeer om die totale afstand wat afgelê word, te verminder.

- Ritkonsolidering: Dit is die vermindering van ritte deur herverdeling.

- Laaipuntaanwysing: Dit behels die vermindering van op- en aflaaipunte langs roetes om die tydsduur van ritte te verkort.

Vrag-, roete- en ritkonsolidering is herhalende bedryfsaksies en word in die opstelwerwe van losmaateindpunte uitgevoer, terwyl laaipuntaanwysing 'n eenmalige vestigingsbesluit is wat die ligging en grootte van losmaateindpunte bepaal (en daarom nie in ' $n$ werf plaasvind nie).

Die uitleg van 'n opstelwerf word oor die wêreld heen ontwerp na gelang van een van drie maniere van rangeerwerk, wat bepaal of die opstelling in 'n bultwerf, 'n gravitasiewerf of 'n platwerf sal plaasvind.

- 'n Bultwerf (of boggelwerf) het 'n mensgemaakte bult waaroor trokke met 'n rangeerlokomotief gerangeer word, en swaartekrag word dan gebruik om die trokke na die verskillende sorteerspore te laat loop.

- 'n Gravitasiewerf is teen 'n natuurlike helling gebou. Rangeerlokomotiewe beheer trokke wat sorteer word aan die helling se opdraandekant, vanwaar hulle ontkoppel en toegelaat word om self na die sorteerspore laer af te loop.

- 'n Platwerf word gebou op plat of byna plat grond en het geen bulte nie. In 'n platwerf word op lokomotiewe gesteun vir alle rangeerbewegings van treinaankomsspore na' $n$ treinstel-opbreekspoor, dan na 'n treinstel-opstelspoor, en laastens na die vertrekspore van die werf. 
'n Eenheidstreinsylyn word onderskei van 'n rangeerwerfsylyn omdat dit beskikbaar is vir eenheidstreine wanneer die bestaande oordrag- en rangeerwerflyne te kort is of deur ander trokke beset word. Eenheidstreine is volledige en vaste treinstelle wat dieselfde trokke het wat loonvrag tussen dieselfde oorsprong en bestemming karwei. Tussen hierdie twee reiseindpunte is eenheidstreine deel van die deurgangsverkeer; hulle word nie in 'n opstelwerf sorteer nie, maar kan in 'n goederewerf op 'n eenheidstreinsylyn stilhou vir ander doeleindes, soos inspeksie, die versiening van lokomotiewe en/of die ruil van bemanning (Symonds Group Ltd 2001:2).

'n Vertrekwerf is die werf waarheen gelaaide treine oorgedra word nadat hulle in 'n opstelwerf saamgestel is. Hier vind inspeksie plaas om te verseker dat die vrag deeglik vasgemaak is en geen merkbare trokfoute voorkom nie. Trokinstandhouding moet beskikbaar wees om klein herstelwerk te doen, byvoorbeeld wanneer die vereiste remvakuum nie geskep kan word nadat die lokomotief gekoppel is nie. (Jukke vir trokkoppeling en remblokke moet in ' $n$ vertrekwerf vir vertrekkende treine beskikbaar wees.)

\section{Hedendaagse goederespoorvervoereindpunte volgens funksie}

Goederespoorvervoereindpunte kan vandag funksioneel in vier breë klasse verdeel word: (1) losmaateindpunte, (2) grootmaateindpunte, (3) opry-afry-eindpunte en (4) intermodale eindpunte (Muller 1995:141-155; Pienaar 2016:252254; Pienaar 2017:85-87; Rail yard 2016; Rickett 2013:11-36; Rodrique 2017:174-175; TFR 2015:2, 30, 73, 89, 100, 103, 193, 194 en 225); Transnet School of Rail, TFR 2014:5-17).

\section{Funksies van losmaateindpunte}

Losmaateindpunte verskaf eindpuntdienste vir onverenigde of trokvragtreine. Losmaateindpunte het dikwels goedereplatforms langs die sylyne vir die op- en aflaai van goedere. Vanweë die behoefte om ook weersensitiewe goedere op te berg wat nie altyd in waterdigte houers verpak is nie, word losmaateindpunte gewoonlik ook deels toegerus met onderdakbergingsgeriewe.

Losmaateindpunte word gewoonlik met 'n opstelwerf geïntegreer. Die hooffunksie van die opstelwerf is die samestelling en verdeling van trokvragtreine wat verskillende soorte onverenigde besendings karwei. Dit is nodig omdat elke trok vir'n ander bestemming bedoel kan wees. Ofskoon losmaateindpunte oorwegend deel van 'n spoorvervoeroperateur se eiendom uitmaak, kan die oorsprong van trokvragverkeer private sylyne wees. Twee voorbeelde hiervan is groepverkeer, wat besendings is wat vragversenders saamgestel het maar aan die spoorvervoeroperateur as ' $n$ enkele trokvrag aangebied word en verkeer wat verband hou met 'n spesifieke aktiwiteit, soos 'n vervaardigingsaanleg of 'n pakhuis wat losmaatgoedere hanteer.
Losmaateindpunte bedien trokvragtreine en die eindpunte is gewoonlik toegerus om die volgende trokke te ontvang: toe trokke, koeltrokke, plattrokke, tenktrokke, oop trokke en systuttrokke.

Op laaisylyne kan daar vaste geriewe soos hyskrane en vervoerbande wees en mobiele toerusting soos vurkhysers, verskuifbare opritte, maneuvreerbare vervoerbande en vragmotorgemonteerde hyskrane. Vurkhysers, verskuifbare opritte en maneuvreerbare losmaatvervoerbande word gebruik om goedere te hanteer wanneer trokke van die kant af gelaai word, en hyskrane word gebruik wanneer oop trokke van bo af gelaai word.

Die eindpuntkomponente waarbinne die onderskeie funksies van losmaateindpunte uitgevoer word, word in Tabel 1 getoon. Die vernaamste liggings- en funksionele aspekte van losmaateindpunte wat in hierdie artikel van belang is, word in Tabel 2 getoon.

\section{Funksies van grootmaateindpunte}

Grootmaateindpunte verskaf eindpuntdienste vir treine wat onverpakte goedere in groot maat vervoer. Grootmaateindpunte word ontwerp om grondstofspesifiek te wees en word toegerus om die loonvrag van treine met baie min rangeerwerk (indien enige) in 'n kort tyd op en af te laai. Dit verkort die staan- en omdraaitye van treine. Om aansienlike volumes buffervoorraad te hou is die belangrikste funksie van grootmaateindpunte - vandaar die naam "grootmaateindpunt".

Grootmaateindpunte is toegerus om óf gelaaide oop trokke (gewoonlik in eenheidstreine) te ontvang, te ontlaai en leeg (gewoonlik steeds in eenheidstreine) af te stuur, óf leë oop trokke (gewoonlik ook in eenheidstreine) te ontvang, te laai en gelaai (steeds in eenheidstreine) af te stuur. Drie kenmerkende voorbeelde is die volgende:

(1) Ertsvertrekeindpunte by myne is ontwerp en toegerus om leë oop trokke te ontvang, te laai en af te stuur; en grootmaatertsbestemmingstasies is toegerus om gelaaide oop trokke te ontvang, te ontlaai en af te stuur, hul loonvrag op te berg en die opgebergde erts met vervoerbande na wagtende skepe of waardetoevoegende fasiliteite te verskuif.

(2) Olieraffinaderye en chemiese aanlegte is ontwerp en toegerus om petroleum- en chemiese produkte te produseer, die geraffineerde produkte in tenkwerwe op te berg en later in tenktrokke te laai deur dit in te pomp of deur ' $n$ dakluik te giet, of dit later per pypleiding weg te voer.

(3) Graansuiers word gebruik om graan in 'n verskeidenheid van relatief klein besendings te ontvang, op te berg, te meng en in bedekte lossertrokke of ander gepaste trokke te laai.

Ertsvertrekeindpunte: In die geval van mynbouprodukte het die ontwikkeling van selflossertrokke (of selfledigende 
trokke), oop kanteltrokke en oop trokke wat onderstebo gedraai kan word, gepaardgegaan met die ontwikkeling van geoutomatiseerde laai-aflaai-geriewe en verwante materiaalhanteringstoerusting, soos vervoerbande wat die afgelaaide goedere by grootmaateindpunte kan verwyder (Pienaar 2017:86).

Selflossertrokke: Hierdie trokke word met swaartekrag ontlaai. Hulle is toegerus met openingsluike aan die onderkant of sykante om die vrag af te laai. Selflossertrokke word van bo af gelaai en deur swaartekrag ontlaai deur tregtervormige lossers aan die onderstel van die trok.

Oop kanteltrokke: Hierdie trokke het hidrouliese, lugdruk- of elektriese kanteltoerusting wat die trokromp aan die een kant kan oplig. Party kanteltrokke kan na enige kant toe kantel, terwyl ander slegs na een kant toe kantel. Om te keer dat trokke tydens kanteling omval, is hulle toegerus met spoorknypstange waarmee hulle stewig aan die spoor geanker kan word.

Oop trokke wat onderstebo gedraai kan word: By eindpunte wat met omkeerders toegerus is, kan hierdie trokke leeggemaak word deur hulle óf linksom óf regsom onderstebo te keer. Dit vereis ' $n$ baie stewige trokonderstel. Hierdie trokke is meesal met roteerbare koppelings toegerus sodat hulle nie individueel ontkoppel hoef te word nie.

Olieraffinaderye en chemiese aanlegte: Om tenktrokke te ontlaai moet die toerusting by die aankomseindpunt geskik wees vir die hantering van -

- kommoditeite wat met lugdrukpompe van die bokant van die trok uitgelaai word (soos die verskeie soorte suur, gas en vlugtige stowwe);

- kommoditeite wat per lugdrukpomp van die onderkant van die trok uitgelaai word (soos flodderstowwe, en verpoeierde en verkorrelde materiaal);

- vloeistowwe wat stol wanneer dit afgekoel het en verhit moet word voordat dit uitgegiet kan word (soos ruolie, teer/bitumen, kreosoot en vet); en

- vloeistowwe wat vryelik van die onderkant van die trok kan uitvloei sonder die noodsaak van pompwerk of verhitting, byvoorbeeld brandstof en drinkbare vloeistowwe.

Graansuiers: In graanproduserende gebiede ontvang hierdie eindpunte los graan per pad deur losservragmotors en vragmotors met kantelbakke (onder "vragmotors" word ook sleep- en leunwaens ingesluit), en by uitvoerhawens deur treine met lossertrokke. Vir vragmotors met niemeganiese kantelbakke moet graansuiers by hulle ontvangspunte met hystoestelle toegerus wees wat aan die optelkant van 'n vragmotor se bak haak en dit oplig sodat die loonvrag aan die bak se skarnierkant sywaarts in 'n ontvangsbak gestort kan word. Losservoertuie stort (ledig) hulle loonvrag vertikaal deur middel van swaartekrag deur tregtervormigeluike aan hulle onderstelle in ontvangsruime wat deel uitmaak van die eindpunt, van waar die ontvangde graan met gekoppelde hanteringsbakke na ontvangs- openinge aan die bopunt van die suiers gedra en in die suiers omgekeer word. By die afsending van graan by ' $n$ binnelandse graansuier vind die laai daarvan in vertrekkende lossertrokke van bo af plaas deur die graanloonvrag deur eindpuntgemonteerde stortkokers in die lossertrokke se loonvragbakke te stort of te laat ingly, en by 'n uitvoerhawe word die graan met gekoppelde hanteringsbakke of met afglygeute van die suier na die skip geneem en in die vragruim gestort.

Die eindpuntkomponente waarbinne die onderskeie funksies van grootmaateindpunte uitgevoer word, word in Tabel 1 getoon. Die vernaamste liggings- en funksionele aspekte van grootmaateindpunte wat in hierdie artikel van belang is, word in Tabel 2 getoon.

\section{Funksies van opry-afry-eindpunte}

Opry-afry-eindpunte word deur eenheidstreine gebruik wat ligte padvoertuie (d.w.s. motors, bakkies, stasiewaens, minibusse, paneelwaens en ligte sleepwaentjies) vervoer; die voertuie word oor 'n op- en 'n afrit in en uit motortrokke gery. Die op- en afritte by eindpunte is ontwerp en toegerus om die loonvrag van treine in 'n kort tyd op of af te laai, met baie min rangeerwerk, indien enige. Dit verminder die staan- en omdraaitye van treine. Op- en afritte is in die meeste gevalle skuifbaar en word soos benodig tydelik aan 'n opry-afry-trok se punt (aan die einde van die trein) geheg vir die opry en afry van die loonvragvoertuie. Op- en afritte word slegs aan die laaste trok van die trein geheg en die loonvragvoertuie word dan binne die trein van trok tot trok gery om dit te laai of te ontlaai. Soms is op-en afritte permanent aan die einde van op-en aflaai-sylyne gemonteer vir oorbrugging tussen die ontvangs- en vertrekwerwe (d.w.s. die loonvragvoertuie se parkeergebiede) en die trein. Hoewel opstelwerwe nie by op- en afry-eindpunte nodig is nie, vereis hierdie eindpunte oor die algemeen 'n groot parkeergebied om die loonvragvoertuie vir buffering te hou, veral by streekverspreidingsentrums, wat gewoonlik as buffergeriewe dien en van waar die streek se kleinhandelafsetpunte bedien word. Opry-afry-trokke is die enigste spoortrokke wat deur hulle punte gelaai en ontlaai word (Pienaar 2017:86)

Die eindpuntkomponente waarbinne die onderskeie funksies van opry-afry-eindpunte uitgevoer word, word in Tabel 1 getoon. Die vernaamste liggings- en funksionele aspekte van opry-afry-eindpunte wat in hierdie artikel van belang is, word in Tabel 2 getoon.

\section{Funksies van intermodale spooreindpunte}

Intermodale spooreindpunte verskaf eindpuntdienste vir houertreine en vir houerskepe en/of houerpadvoertuie. Dié dienste sluit in die ontvangs en laai, aflaai en versending, transito-opberging en tussenvoertuigoordrag van standaard- intermodale houers.

Behouering het die produktiwiteit van spooreindpunte aansienlik verbeter aangesien dit die vinnige laai, aflaai en 
oorlaai van die vrag daarin moontlik maak. Hierdie toename in produktiwiteit word behaal deur goeie toegang tot 'n hawe en/of die padstelsel, gesteun deur geoutomatiseerde hanteringsbedrywighede om aan die goedereoordragvereistes van moderne intermodale spoorbedrywighede te voldoen (Pienaar 2017:86). Laasgenoemde verg egter aansienlike vaste investering in geskikte ruimte vir eindpuntgeriewe en in hanteringstoerusting: Eerstens vereis intermodale eindpunte investering in geplaveide platforms en oppervlakke vir houerhanteringstoerusting en opbergingsruimte vir die buffering van houers.

Tweedens, na gelang van die soort bedrywigheid, word spesifieke intermodale hanteringstoerusting gebruik. Die keuse hiervan hang af van (1) toerustingspesifieke faktore, naamlik (a) die vereiste kapitaalinvestering, (b) die instandhouding van toerusting, en (c) die gebruik van gespesialiseerde toerustingoperateurs, en van (2) bedryfsfaktore soos (a) produktiwiteitsdoelwitte, (b) verkeersvolume, (c) die behoefte om houers regstreeks tussen voertuie (spoor, pad en skepe) te kan oorlaai of om houers te kan opberg, en (d) hoe dig houers opgestapel kan word wanneer hulle opgeberg word. Houerhanteringstoerusting sluit in kanthysers, voorpunthysers, reikstapelaars, buidelwaens (insluitende gryphysers) en bokkrane (Hinkelman 2018: 100, 166, 185; Muller 1995:146-155; Pienaar 2017:86; Ricket 2013:21-26; Rushton, Croucher en Baker 2014:418-425).
Die eindpuntkomponente waarbinne die onderskeie funksies van intermodale eindpunte uitgevoer word, word in Tabel 1 getoon. Die vernaamste liggings- en funksionele aspekte van intermodale spooreindpunte wat in hierdie artikel van belang is, word in Tabel 2 getoon.

\section{Gevolgtrekkings}

Goederevervoereindpunte vervul verkeersfunksies, wat hulle primêre funksies is, en voertuigfunksies, wat hulle sekondêre funksies is. Daar is vyf primêre verkeersfunksies, naamlik dié van (1) toegangs- en uitgangsverlening, (2) buffering, (3) goedereoordrag, (4) vragkonsolidering en (5) vragverdeling.

Toegangs- en uitgangsverlening verwys na die ontvangs van versenders se goedere van buite die vervoerstelsel en die lossing van ontvangers se goedere na buite die vervoerstelsel.

Buffering het betrekking op die opberg van aangekome goedere in 'n transitopakhuis en die latere onttrekking daarvan uit opberging namate dit vir aansending benodig word.

Goedereoordrag vind plaas deur -

- die regstreekse oorlaai van goedere van aangekome voertuie af na voertuie in dieselfde vervoermodus of in ander vervoermodusse wat op vertrek staan;

TABEL 1: Werftipes waarbinne die onderskeie funksies van goederespoorvervoereindpunte uitgevoer word

\begin{tabular}{|c|c|c|c|c|}
\hline Funksie & Losmaateindpunte & Grootmaateindpunte & Opry-afry-eindpunte & Intermodale eindpunte \\
\hline Toegang tot vervoerstelsel & $\begin{array}{l}\text { Van buite via sylyn na } \\
\text { ontvangswerf en ontvangs van } \\
\text { volgepakte los houers per pad } \\
\text { vanaf afsenders }\end{array}$ & $\begin{array}{l}\text { Sylyn by produksiepunt se } \\
\text { opslagplek (in oopte of by } \\
\text { tenkwerf of by graansuiers) }\end{array}$ & $\begin{array}{l}\text { Met oprit by parkeerterreine by } \\
\text { voertuigfabrieke }\end{array}$ & Sylyne by lokuspunte \\
\hline Uitgang vanaf vervoerstelsel & $\begin{array}{l}\text { Uit vertrekwerf via sylyn na } \\
\text { buite }\end{array}$ & $\begin{array}{l}\text { Aflaaipunt by bestemming } \\
\text { se opslagplek (in oopte of by } \\
\text { tenkwerf of by graansuiers) }\end{array}$ & $\begin{array}{l}\text { Met afrit by parkeerterreine by } \\
\text { streeks-verspreidingspunte }\end{array}$ & Sylyne by lokuspunte \\
\hline Buffering & $\begin{array}{l}\text { Parkeerwerflyne en loodse } \\
\text { langs sylyne }\end{array}$ & $\begin{array}{l}\text { Opslagplek (in oopte of by } \\
\text { tenkwerf of by graansuiers) }\end{array}$ & $\begin{array}{l}\text { Parkeerterreine by fabrieke, } \\
\text { hawens en distribusiepunte }\end{array}$ & $\begin{array}{l}\text { Nabykaai-houeropbergruimtes } \\
\text { Eenheidstreinsylyne by lokus- } \\
\text { punte }\end{array}$ \\
\hline Goedereoordrag & Opstelwerf & $\begin{array}{l}\text { Eenheidstrein-eindpunte by } \\
\text { hawens }\end{array}$ & Opry-afry-spooreindpunte & Intermodale eindpunte \\
\hline Vragkonsolidering & Opstelwerf & Toegangspunt & $\begin{array}{l}\text { Parkeerterreine by opry-afry- } \\
\text { eindpunte }\end{array}$ & Intermodale eindpunte \\
\hline Vragverdeling & Opstelwerf & Uitgangspunt & $\begin{array}{l}\text { Parkeerterreine by sylyne se } \\
\text { eindpunte }\end{array}$ & Intermodale eindpunte \\
\hline Voertuiginspeksie & Ontvangswerf & $\begin{array}{l}\text { Eindpunte waar grootmaat- } \\
\text { eenheidstreine aandoen }\end{array}$ & $\begin{array}{l}\text { Eindpunte waar opry-afry- } \\
\text { treine aandoen }\end{array}$ & $\begin{array}{l}\text { Eindpunte waar houertreine } \\
\text { aandoen }\end{array}$ \\
\hline Brandstofhervulling & $\begin{array}{l}\text { Lokomotiefdepot indien diesel; } \\
\text { n.v.t. vir elektries }\end{array}$ & $\begin{array}{l}\text { Lokomotiefdepot indien diesel; } \\
\text { n.v.t. vir elektries }\end{array}$ & $\begin{array}{l}\text { Lokomotiefdepot indien diesel; } \\
\text { n.v.t. vir elektries }\end{array}$ & $\begin{array}{l}\text { Lokomotiefdepot indien diesel; } \\
\text { n.v.t. vir elektries }\end{array}$ \\
\hline Instandhouding & Herstelwerf en lokomotiefdepot & $\begin{array}{l}\text { Herstelwerf en } \\
\text { lokomotiefdepot }\end{array}$ & Herstelwerf en lokomotiefdepot & Herstelwerf en lokomotiefdepot \\
\hline Parkering & Parkeersylyne langs opstelwerf & $\begin{array}{l}\text { Eenheidstreinsylyne by eind- } \\
\text { punte }\end{array}$ & $\begin{array}{l}\text { Eenheidstreinsylyne by eind- } \\
\text { punte }\end{array}$ & $\begin{array}{l}\text { Eenheidstreinsylyne by eind- } \\
\text { punte }\end{array}$ \\
\hline
\end{tabular}


TABEL 2: Liggings- en funksionele aspekte van goederespoorvervoereindpunte

\begin{tabular}{|c|c|c|c|}
\hline $\begin{array}{l}\text { TIPE EINDPUNTE EN HULLE LIGGINGS } \\
\text { Losmaateindpunte } \\
\text { Klein goederewerf - teenaan 'n } \\
\text { passasierstasie } \\
\text { Middelslag- en groot goederewerf - } \\
\text { met sylyn verbind met geassosieerde } \\
\text { passasierstasie } \\
\text { Groot en onafhanklike goederewerf op } \\
\text { private sylynkompleks }\end{array}$ & $\begin{array}{l}\text { TIPE TREIN EN TROKKE BEDIEN } \\
\text { Trokvragtrein: } \\
\text { Toe trokke } \\
\text { Koeltrokke } \\
\text { Plat trokke } \\
\text { Tenktrokke } \\
\text { Oop trokke } \\
\text { Systuttrokke }\end{array}$ & $\begin{array}{l}\text { HANTERINGSTOERUSTING BENUT } \\
\text { Gemonteer: } \\
\text { Hyskrane en vervoerbande } \\
\text { Mobiel: } \\
\text { Vurkhysers } \\
\text { Verskuifbare op- en afritte } \\
\text { Maneuvreerbare vervoerbande } \\
\text { Vragmotorgemonteerde hyskrane }\end{array}$ & $\begin{array}{l}\text { GOEDERESOORTE HANTEER } \\
\text { Items wat nie gepas is vir } \\
\text { standaardbehouering of } \\
\text { grootmaatvervoer nie (kan wel items in } \\
\text { enkele standaard- intermodale houers } \\
\text { en vloeistof in enkele tenktrokke wees } \\
\text { wat as losmaatgoedere voorkom) }\end{array}$ \\
\hline $\begin{array}{l}\text { Ertseindpunte } \\
\text { Op private sylyne by myne, kragstasies } \\
\text { en verwerkingsaanlegte } \\
\text { Sylyne by invoerhawens en } \\
\text { uitvoerhawens }\end{array}$ & $\begin{array}{l}\text { Eenheidstrein: } \\
\text { Oop lossertrokke } \\
\text { Oop trokke wat kantelbaar of } \\
\text { omkeerbaar is }\end{array}$ & $\begin{array}{l}\text { Trokkantelaars } \\
\text { Trok-omkeerders } \\
\text { Vervoerbande om goedere af te voer of } \\
\text { toe te voer }\end{array}$ & $\begin{array}{l}\text { Ertse - meesal yster, mangaan, koper, } \\
\text { graniet, chroom en steenkool }\end{array}$ \\
\hline $\begin{array}{l}\text { Tenktrokeindpunte } \\
\text { Op private sylyne by raffinaderye en } \\
\text { tenkwerwe (pypleidings tussen invoer-/ } \\
\text { uitvoerhawens en naaste tenkwerf of } \\
\text { raffinadery) }\end{array}$ & $\begin{array}{l}\text { Eenheidstrein: } \\
\text { Tenktrokke }\end{array}$ & $\begin{array}{l}\text { Lugdrukpompe vir die vul en leegmaak } \\
\text { aan bokant en onderkant van trokke } \\
\text { Buigsame pype wat eindpunttenks } \\
\text { koppel met tenktrokke }\end{array}$ & $\begin{array}{l}\text { Ruolie } \\
\text { Brandstof - meesal petrol, diesel, } \\
\text { paraffien en vliegtuigbrandstof } \\
\text { Chemiese produkte - meesal sure } \\
\text { Aardgas }\end{array}$ \\
\hline $\begin{array}{l}\text { Graaneindpunte } \\
\text { By graansuiers op private en } \\
\text { operateursylyne in produksiegebiede en } \\
\text { by invoer- en uitvoerhawens }\end{array}$ & $\begin{array}{l}\text { Eenheidstrein: } \\
\text { Bedekte lossertrokke }\end{array}$ & $\begin{array}{l}\text { Padvoertuigkantelaars } \\
\text { Gekoppelde hanteringsbakke } \\
\text { Vervoerbande } \\
\text { Gemonteerde stortkokers } \\
\text { en afglygeute } \\
\text { Ontvangsbakke en ruime }\end{array}$ & $\begin{array}{l}\text { Grootmaatgraan - meesal mielies en } \\
\text { koring }\end{array}$ \\
\hline $\begin{array}{l}\text { Opry-afry-eindpunte } \\
\text { Op private en operateursylyne } \\
\text { by voertuigfabrieke, } \\
\text { streeksdistribusiepunte, en invoer- en } \\
\text { uitvoerhawens }\end{array}$ & $\begin{array}{l}\text { Eenheidstrein: } \\
\text { Motortrokke }\end{array}$ & $\begin{array}{l}\text { Gemonteerde en maneuvreerbare op- } \\
\text { en afritte }\end{array}$ & $\begin{array}{l}\text { Ligte padvoertuie: } \\
\text { Motors, minibusse, paneelwaens, } \\
\text { bakkies, stasiewaens en ligte } \\
\text { sleepwaentjies }\end{array}$ \\
\hline $\begin{array}{l}\text { Intermodale eindpunte } \\
\text { Op private en operateursylyne by } \\
\text { invoer- en uitvoerhawens (aan kaai en } \\
\text { naby kaai) } \\
\text { Operateursylyne by aansluitstasies } \\
\text { Private alleenstaande sylynkomplekse by } \\
\text { lokuspunte in nywerheidsgebiede }\end{array}$ & $\begin{array}{l}\text { Eenheidstrein: } \\
\text { Plat trokke } \\
\text { Puttrokke }\end{array}$ & $\begin{array}{l}\text { Kanthysers } \\
\text { Voorpunthysers } \\
\text { Reikstapelaars } \\
\text { Buidelwaens (insluitende gryphysers) } \\
\text { Bokkrane }\end{array}$ & $\begin{array}{l}\text { Enige halfvoltooide en voltooide items } \\
\text { wat in standaard- intermodale houers } \\
\text { pas. }\end{array}$ \\
\hline
\end{tabular}

Bron: Eie navorsing

- kruisversending, wat behels dat goedere van aangekome voertuie af op 'n platform of 'n dok geplaas word, waar dit oorstaan totdat dit later op vertrekkende voertuie gelaai word; of

- herverskeping, wat behels dat goedere ná buffering gelaai word op voertuie wat gaan vertrek.

Vragkonsolidering vind plaas wanneer 'n verskeidenheid van klein besendings ontvang en tot groter vragbesendings vir langafstandversending gekombineer word. Vragkonsolidering help om voertuigdravermoë ten beste te benut.

Vragverdeling vind plaas wanneer groot vragte in kleiner vrageenhede geskei word. Dit vind merendeels by intermodale lokuseindpunte plaas, waar houers van aangekome houertrokke na houerpadvoertuie oorgeplaas word, of by opstelwerwe, waar voltrokvragte losmaatgoedere, tenktrokke en houertrokke wat deel van 'n trokvragtrein is, ontkoppel en op 'n private sylyn afgelewer word.
Goederevervoereindpunte verskaf ook voertuiggerigte funksies. Afhangende van die grootte van die eindpunt kan dit voertuiginspeksie, brandstofhervulling, die parkering van voertuie, en instandhouding van en herstelwerk aan voertuie en toerusting insluit.

Goederespoorvervoereindpunte kan vandag funksioneel in vier breë klasse verdeel word: losmaateindpunte, grootmaateindpunte, opry-afry-eindpunte en intermodale eindpunte.

(1) Losmaateindpunte verskaf eindpuntdienste vir trokvragtreine. Losmaateindpunte het dikwels goedereplatforms langs die sylyne vir die op- en aflaai van goedere. Op laaisylyne kan daar vaste geriewe soos hyskrane en vervoerbande wees en mobiele toerusting soos vurkhysers, verskuifbare opritte, maneuvreerbare vervoerbande en vragmotorgemonteerde krane. Vurkhysers, verskuifbare opritte en maneuvreerbare losmaatvervoerbande word gebruik om goedere te hanteer wanneer trokke van die kant af gelaai word, en hyskrane word gebruik wanneer oop trokke van bo af gelaai word. 
(2) Grootmaateindpunte verskaf eindpuntdienste vir treine wat onverpakte goedere in groot maat vervoer. Grootmaateindpunte word ontwerp om grondstofspesifiek te wees en word toegerus om die loonvrag van treine met baie min rangeerwerk (indien enige) binne 'n kort tyd te laai of af te laai. Grootmaateindpunte is toegerus om óf gelaaide oop trokke (gewoonlik in eenheidstreine) te ontvang, te ontlaai en die leë oop trokke (gewoonlik steeds in eenheidstreine) af te stuur, óf leë oop trokke (gewoonlik in eenheidstreine) te ontvang, te laai en die gelaaide trokke (steeds in eenheidstreine) af te stuur. Drie kenmerkende voorbeelde is: (i) ertsvertrekeindpunte by myne, wat ontwerp en toegerus is om leë oop trokke te ontvang, te laai en af te stuur; en ertsbestemmingseindpunte, wat toegerus is om gelaaide oop trokke te ontvang, te ontlaai en af te stuur, die loonvrag op te berg en die opgebergde erts met vervoerbande na wagtende skepe of waardetoevoegende fasiliteite te karwei; (ii) olieraffinaderye en chemiese aanlegte, wat ontwerp en toegerus is om petroleum- en chemiese produkte te produseer en die geraffineerde produkte in tenkwerwe op te berg en later in tenktrokke in te pomp of deur 'n dakluik in te giet, of per pypleiding weg te voer; en (iii) graansuiers, wat gebruik word om graan in 'n verskeidenheid van relatief klein besendings te ontvang, op te berg, te meng en in bedekte lossertrokke of ander gepaste trokke te laai.

(3) Opry-afry-eindpunte word deur eenheidstreine gebruik wat ligte padvoertuie vervoer in trokke waaraan 'n op- en afrit vir die voertuie geheg kan word. Die op- en afritte by eindpunte is ontwerp en toegerus om die loonvrag van treine binne 'n kort tyd op of af te laai, met baie min rangeerwerk, indien enige. Hoewel opstelwerwe nie by opry-afry-eindpunte nodig is nie, vereis hierdie eindpunte oor die algemeen 'n groot parkeergebied om die loonvragvoertuie te hou, veral by streekverspreidingsentrums, wat gewoonlik as buffergeriewe dien van waar die streek se kleinhandelafsetpunte bedien word.

(4) Intermodale spooreindpunte verskaf eindpuntdienste vir houertreine en vir houerskepe en/of houerpadvoertuie. Dié dienste sluit in die ontvangs en laai, aflaai en versending, transito-opberging en tussenvoertuigoordrag van standaard- intermodale houers.

Behouering het die produktiwiteit van spooreindpunte aansienlik verbeter aangesien dit die vinnige laai, aflaai en oorlaai van die vrag daarin moontlik maak. Hierdie toename in produktiwiteit word behaal deur goeie toegang tot 'n hawe en/of die padstelsel, gesteun deur geoutomati- seerde hanteringsbedrywighede om aan die vragoordragvereistes van moderne intermodale spoorbedrywighede te voldoen.

Die toename in intermodale eindpuntproduktiwiteit verg egter aansienlike vaste investering in geskikte ruimte vir eindpuntgeriewe en in hanteringstoerusting: Eerstens vereis intermodale eindpunte kapitaalinvestering in geplaveideplatforms, oppervlakkevirhouerhanteringstoerusting en opbergingsruimte vir die buffering van houers. Tweedens, afhangende van die soort bedrywigheid, word spesifieke intermodale hanteringstoerusting gebruik, wat groot kapitaalbesteding verg.

Houerhanteringstoerusting sluit in kanthysers, voorpunthysers, reikstapelaars, buidelwaens (insluitende gryphysers) en bokkrane.

\section{Verwysings}

Benson D, Whitehead G. 1975. Transport and Distribution. W.H. Allen, London.

Faulks RW. 1982. Principles of transport, 3rd edition. Ian Allen, London.

Hinkelman EG. 2018. Dictionary of International Trade, 12th edition. World Trade Press, Petaluma, California.

Muller G. 1995. Intermodal Freight Transportation, 3rd edition. Eno Transportation Foundation, Lansdowne, VA, USA.

Pienaar WJ. 2016. The influence of size, location and functions of freight rai terminals on urban form and land use. Corporate Ownership and Control 2016 13(3), 251-256.

Pienaar WJ. 2017. Bedryfs- en tegnologiese vereistes vir die winsgewende lewering van spoorgoederevervoer. Suid-Afrikaanse Tydskrif vir Natuurwetenskap en Tegnologie 36(1), 79-89.

Pienaar WJ. 2019. Goederevervoermarksegmente wat potensieel winsgewend deur spoorvervoer bedien kan word. Suid-Afrikaanse Tydskrif vir Natuurwetenskap en Tegnologie 38(1), 168-179.

Pienaar WJ. 2020. Liggingsaspekte van spoorvervoereindpunte wat die winsgewendheid van goederespoordienste ondersteun. Suid-Afrikaanse
Tydskrif vir Natuurwetenskap en Tegnologie 39(1), (Published ahead of print).

RailNetEurope (RNE). 2014. Glossary of Terms Related to Railway Network Statements, 6th Edition. RailNetEurope, Vienna.

Rail yard, 2016. Available: https://en.wikipedia.org/wiki/Rail_yard (accessed on 18 August 2016).

Rickett TG. 2013. Intermodal train loading methods and their effect on intermodal terminal operations. Thesis submitted in partial fulfilment of the degree of MS in Civil Engineering, University of Illinois at Urbana-Champaign.

Rodrique J-P. 2017. The Geography of Transport Systems, 4th edition. Routledge, London.

Rushton A, Croucher P, Baker P. 2014. The Handbook of Logistics and Distribution Management, 5th edition. The Chartered Institute of Logistics and Transport, London.

Symonds Group Ltd. 2001. A Study of Single Wagonload Rail Traffic. DirectorateGeneral for Energy \& Transport, European Commission, Brussels.

Transnet Freight Rail (TFR). 2015. Wagon Book. Transnet Freight Rail, Johannesburg.

Transnet School of Rail. 2014. Functional Yard Operations. Reference FYO_08: Yard Layout. Transnet Freight Rail, Johannesburg. 